\title{
因防 prakatild)e 伊aldhinenwärter
}

\author{
Sulleitıtut \\ jür

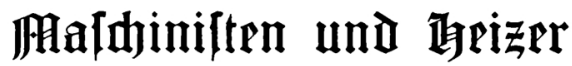 \\ joipie zum

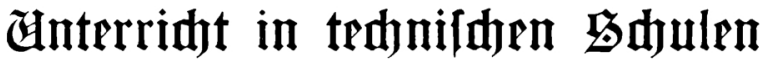 \\ voll \\ Baul Brauler, und

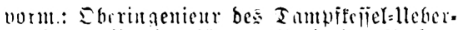

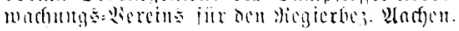 \\ Iolpph Eppenurath, \\ secil. Eircftur ber geiverhlicten

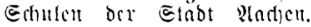

JApubparbritpt vall $\mathfrak{2}$. Bant,

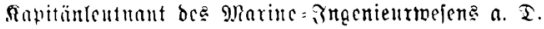

T) Apunte 解uflage.

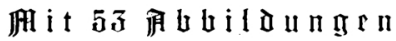

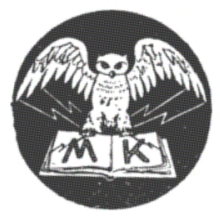

Brrlin W.

Berlag von Mi. Siralyn.

1926. 
